\title{
DISTURBANCE OF THE TRANSMEMBRANE PHOSPHATIDYLSERINE ASYMMETRY IN HEPATOCYTES AS AN APOPTOSIS MARKER UNDER THE ACTION OF XENOBIOTICS ON RATS
}

\author{
O. A. NAKONECHNA, L. A. BABIJCHUK, A. I. BEZRODNA \\ Kharkiv National Medical University, Kharkiv, Ukraine; \\ e-mail: bezrodnaya.ai@gmail.com
}

\begin{abstract}
It has been reported that unfavorable chemical environmental factors affect the functional state of liver, activate free radical processes against the background of the reduced antioxidant activity, change physicochemical properties and membrane phospholipid composition of hepatocytes. The aim of our research was to estimate phosphatidylserine distribution in the phospholipid bilayer of hepatocyte membranes and apoptosis stages in hepatocytes of rats under the influence of surfactants: ethyleneglycol (EG), polyethyleneglycol 400, (PEG-400) and polypropyleneglycol (PPG) at a dose of 1/10 DL ${ }_{50}$. It was found in the subacute toxicological experiment on rats that the investigated xenobiotics EG, PEG-400 and PPG at a dose of $1 / 10 D L_{50}$ caused phosphatidylserine translocation to the outer membrane in the phospholipid bilayer of hepatocytes. This is a specific signal for macrophages aiming at recognition and elimination of apoptotic cells. Analysis of cell death modes under the influence of the investigated xenobiotics at a dose of $1 / 10 D L_{50}$ revealed that the intake of xenobiotics was associated with an increase in the amount of apoptotic / necrotic hepatocytes.
\end{abstract}

Ke y w o rd s: xenobiotics, membrane, phospholipid bilayer of hepatocytes, phosphatidylserine, apoptosis.

$\mathrm{T}$ he use of constantly growing range of cosmetics and detergents, washing powders and modern building materials in the everyday life of Ukrainians determines the increasing role of surfactants in all fields of human activities [1-3].

Xenobiotics are in close contact with the human body irrespective of sex, age, profession, state of health, etc. Experts have found that $42 \%$ of surfactants enter sewage waters, $22 \%$ are released in the atmospheric air, $12 \%$ are dumped, $7 \%$ pollute settlements , $11 \%$ pollute household plots, and $6 \%$ remain in living buildings $[4,5]$. The global technoanthropogenic load of surfactants on environmental objects has been confirmed by the official data of the State Statistics Service of Ukraine [6].

Based on the results of numerous experimental studies on warm-blooded animals, it has been established that surfactants modulate radiomimetic effects in biological objects and stimulate the development of free radical pathology, which in turn leads to the development of membrane pathology [7-9]. The long- term intake of surfactants results in deep reorganization of the intracellular metabolism, neurotransmitter imbalance and impaired kinetic characteristics of ligand binding in a dose-dependent manner [10-13]. Xenobiotics-mediated epigenetic modulations play a key role in cell differentiation during early life and across the life span, since xenobiotics can significantly affect gene expression in a cell- and tissuespecific manner $[14,15]$.

It has been known that unfavorable chemical factors can affect cell components, namely cell membranes [9]. It has been reported that surfactants have toxic effects on the liver $[11,13]$. However, the rate and modes of hepatocyte cell death under the influence of them has not been yet studied.

The aim of our study was to estimate phosphatidylserine distribution in the phospholipid bilayer of hepatocytes and cell death modes of hepatcytes under the influence of surfactants: ethylene glycol (EG), polyethylene glycol 400 (PEG-400) and polypropylene glycol (PPG) at a dose of $1 / 10 \mathrm{DL}_{50}$.

\footnotetext{
(C) 2018 Nakonechna O. A. et al. This is an open-access article distributed under the terms of the Creative Commons Attribution License, which permits unrestricted use, distribution, and reproduction in any medium, provided the original author and source are credited.
} 


\section{Materials and Methods}

The study was performed during 45 days on 30 WAG white rats of both sexes. Animals were kept in the standard conditions of the vivarium. Monitoring of animals was carried out in accordance with the provisions of the "General Principles of Animal Experiments" approved by the First National Congress on Bioethics (Kiev, 2001), "European Convention for the Protection of Vertebrates used for experimental and scientific purposes" (Strasbourg, 1986).

The experiment was performed using four groups of animals: a control group and three groups of experimental animals in the amount of 10 animals in each. Solutions of surfactants (ethyleneglycol, polyethyleneglycol and polypropyleneglycol) were injected daily intragastrically at a dose of $1 / 10 \mathrm{DL}_{50}$ using a metal gavage. $1 / 10 \mathrm{DL}_{50}$ for ethylene glycol was $0.55 \mathrm{~g} / \mathrm{kg}$ of body weight, whereas it was 2.89 and $3.25 \mathrm{~g} / \mathrm{kg}$ of body weight for polyethyleneglycol and polypropyleneglycol, respectively [16]. The control group of rats received the corresponding volumes of drinking water. After the end of the 45-daylong subacute toxicological experiment, rats were killed in accordance with the "International Recommendations for Conducting Biomedical Studies Using Laboratory Animals” by decapitation. Liver perfusion and isolation of hepatocytes were performed according to A.Yu. Petrenko [17]. The abdominal cavity was opened, the injection needle was inserted into the portal vein and fixed with a ligature at the site of the right renal vein for the outflow of perfusate. At the first stage, the liver was washed from blood at a rate of $25-35 \mathrm{ml} / \mathrm{min}$ with a solution containing $140 \mathrm{mM}$ of sodium chloride, $5 \mathrm{mM}$ of potassium chloride, $3 \mathrm{mM}$ of sodium bicarbonate and $27 \mathrm{mM}$ of sodium citrate saturated with a mixture of $95 \% \mathrm{O}_{2}$ and $5 \% \mathrm{CO}_{2}$ to $\mathrm{pH} 7.4$ for $10 \mathrm{~min}$ at $37^{\circ} \mathrm{C}$ at a rate of $25-35 \mathrm{ml} / \mathrm{min}$. At the second stage, perfusion was performed at the same rate for 20-30 min. At this stage, EDTA was added to the solution at a final concentration of $2 \mathrm{mM}$. Upon finishing the perfusion, the liver was removed from the abdomen, quickly cooled to $0{ }^{\circ} \mathrm{C}$ and cut into pieces in a solution containing $250 \mathrm{mM}$ sucrose, $5 \mathrm{mM} \mathrm{KCl}$, $1.6 \mathrm{mM} \mathrm{Na}_{2} \mathrm{HPO}_{4}, 0.4 \mathrm{mM} \mathrm{KH}_{2} \mathrm{PO}_{4}, 0.8 \mathrm{mM} \mathrm{MgCl}_{2}$, $1.2 \mathrm{mM} \mathrm{CaCl}_{2}$ and $1 \%$ albumin (pH 7.4). The tissue pieces were homogenized in a cooled sucrose-salt solution, then suspension of hepatocytes obtained as a result of homogenization was filtered through nylon and centrifuged at $50 \mathrm{~g}$ for $4 \mathrm{~min}$. Homogenization was performed by vibration. Tissue pieces underwent vibration in a cooled sucrose-salt medium at a frequency of $50 \mathrm{~Hz}$ during $60 \mathrm{sec}$ using a device whose electric engine sets a pestle in motion.

Suspension was divided into 2 fractions: the lower dark fraction and the upper light fraction. Fractions were isolated and suspended in a saline solution containing $140 \mathrm{mM} \mathrm{NaCl}, 5 \mathrm{mM} \mathrm{KCl}, 0.8 \mathrm{mM}$ $\mathrm{MgSO}_{4}, 1.6 \mathrm{mM} \mathrm{Na}_{2} \mathrm{HPO}_{4}, 0.4 \mathrm{mM} \mathrm{K}_{2} \mathrm{HPO}_{4}, 25 \mathrm{mM}$ $\mathrm{NaHCO}_{3}$ and $1 \mathrm{mM} \mathrm{CaCl}_{2}(\mathrm{pH} 7,4)$. We used the lower dark fraction. One $\mathrm{ml}$ of it contains $110 \cdot 10^{6}$ hepatocytes.

The degree of lipid membrane asymmetry and the apoptosis/necrosis stages were evaluated by flow cytometry on a FACS Calibur flow cytometer from Becton Dickinson (BD) (USA) using the AnnexinV-FITC detection KIT of BD Pharmingen in accordance with the AnnexinV-FITC 1 and 7-aminoactinomycin D (7-AAD) (BD Pharmingen) protocols. The study was conducted in the department of cryocytology of the Institute of Problems of Cryobiology and Cryomedicine of NAS of Ukraine.

Phosphotidylserine exposure on the surface of rat hepatocytes was assessed by flow cytometry using FITC-labeled Annexin V, which has a highly specific affinity to negatively charged phospholipids, in particular to phosphatidylserine, normally located on the inner surface of the cell membrane bilayer [18-20].

Evaluation of the apoptosis/necrosis stages was performed using the combination of Annexin $\mathrm{V}$ and 7-AAD [18]. This method allows identifying four different cell states: viable cells (AnnexinV-7AAD-cells); cells in the initial stage of apoptosis with the integral membrane impermeable to 7-AAD (AnnexinV+7AAD-cells), dead or dying cells in the stage of late apoptosis/necrosis (AnnexinV ${ }^{+}$7AAD ${ }^{+}$-cells), dead necrotic cells that are stained with 7-AAD but are not able to bind Annexin $\mathrm{V}$ (AnnexinV-7AAD ${ }^{+}$-cells) [18-22]. To minimize the error probability, 50,000 events were analyzed in the samples.

\section{Results and Discussion}

Cell-cell interactions regulate cell death in two fundamental ways. First, cells require specific protein hormonal signals to stay alive. In the absence of such survival signals, cells activate a "suicide" program. The second way includes the immune system and other specific hormonal signals and induces a programmed cell death. Cell death is most frequently mediated by a common molecular path- 
way termed apoptosis. Another form of cell death is called necrosis and occurs when cells are subjected to excessive stresses: lack of oxygen, heat, etc. Cells become swollen and burst, releasing their intracellular contents.

The phosholipid phosphatidylserine is normally found in the inner, cytosolic leaflet of the membrane. During apoptosis the increased amounts of phosphatidylserine are found in the exoplasmatic leaflet, where it acts as an "eat me" signal [23].

Hepatocytes have been proved to be a good tool for analyzing the oxidative stress of toxic action in various studies [13].

It was found that the investigated xenobiotics at a dose of $1 / 10 \mathrm{DL}_{50}$ led to imbalance in the asymmetry of the distribution of phospholipids in the plasma membrane of hepatocytes, phosphatidylserine translocation from the inner layer into the outer layer. The degree of phosphatidylserine asymmetry changes in hepatocyte membranes under the action of the investigated xenobiotics is shown in Fig. 1.

The most pronounced structural changes in the phospholipid bilayer of membranes were observed as a result of the action of PEG-400. Phosphatidylserine is expressed in the outer layer in $24.87 \pm 3.07 \%$ of hepatocytes $(P<0.05$ in comparison with the control). Almost the identical percentage of hepatocytes with phosphatidylserine in the outer membrane was observed for rats administered EG and PPG (15.21 $\pm 2.15 \%$ and $14.54 \pm 2.93 \%$ respectively).

In this study, we showed that after toxification of white rats with xenobiotics at a dose of $1 / 10 \mathrm{DL}_{50}$, the rate of early apoptosis was higher compared with control animals. This indicates activation of hepatocyte apoptosis (Fig. 2, A, B).

We evaluated the apoptosis/necrosis stages of cells using the combination of Annexin $\mathrm{V}$ and 7 -AAD dye $[18,22]$. The latter easily penetrates the damaged plasma membrane whose integrity is lost in the late stage of apoptosis and in necrosis. However, 7-AAD does not pass through the intact cell membrane of viable cells.

Evaluation of cell death modes after prolonged oral intake of $1 / 10 \mathrm{DL}_{50}$ of ethylene glycol showed that the percentage of viable AnnexinV-7AAD- cells was $76.54 \%$. The amount of AnnexinV ${ }^{+}$AAD ${ }^{-}$cells at the initial stage of apoptosis was $14.98 \%$. The percentage of AnnexinV-7AAD ${ }^{+}$dead necrotic cells was $1.67 \%$ and the amount of AnnexinV ${ }^{+} 7 \mathrm{AAD}^{+}$dead or dying cells, which were at the stage of late apoptosis / necrosis was $6.87 \%$ (Fig. 2, B).

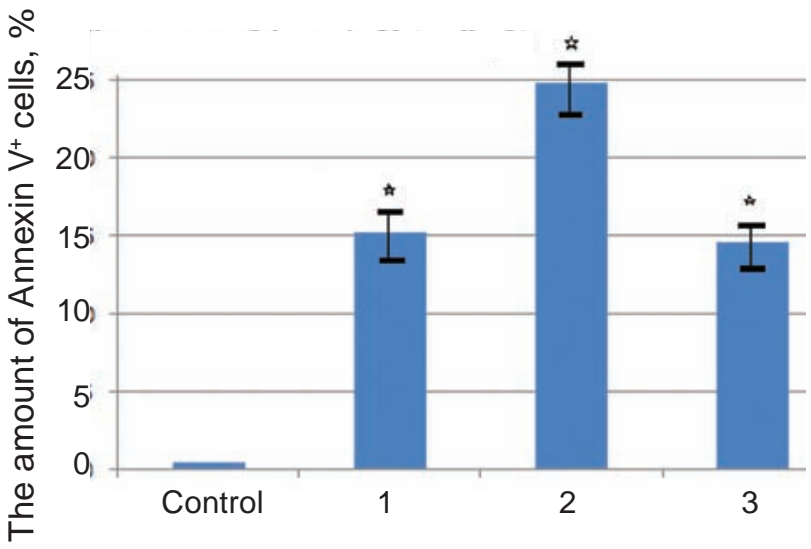

Fig. 1. The amount of AnnexinV $V^{+}$hepatocytes from rats after prolonged consumption of xenobiotics at a dose of 1/10 DL ${ }_{50}$ : 1-ethyleneglycol (EG); 2-polyethyleneglycol-400 (PEG-400); 3-polypropyleneglycol (PPG) The data are presented in the form of $M \pm S E . *$ is a statistical significance of $P<0.05$ in comparison with the control

Evaluation of cell death modes after prolonged oral consumption of $1 / 10 \mathrm{DL}_{50}$ of polyethylene glycol-400 showed that the percentage of viable AnnexinV-7AAD' cells was $60.70 \%$. The amount of AnnexinV ${ }^{+} 7 \mathrm{AAD}^{-}$cells at the initial stage of apoptosis was $25.50 \%$. The percentage of AnnexinV-7AAD ${ }^{+}$ dead necrotic cells was $0.04 \%$ and the amount of AnnexinV ${ }^{+} 7 \mathrm{AAD}^{+}$dead or dying cells, which are at the stage of late apoptosis/necrosis was $13.76 \%$ (Fig. 3, A).

Evaluation of cell death modes after prolonged oral consumption of $1 / 10 \mathrm{DL}_{50}$ of polyethyleneglycol-400 showed that the percentage of viable AnnexinV-7AAD' cells was $77.63 \%$. The amount of AnnexinV ${ }^{+}$7AAD ${ }^{-}$cells at the initial stage of apoptosis was $14.86 \%$. The percentage of AnnexinV-7AAD ${ }^{+}$ dead necrotic cells was $0.14 \%$ and the amount of AnnexinV ${ }^{+} 7 \mathrm{AAD}^{+}$dead or dying cells, which are at the stage of late apoptosis / necrosis was $7.37 \%$ (Fig. 3, B).

The percentage of AnnexinV-7AAD', AnnexinV ${ }^{+}$AAAD ${ }^{-}$, AnnexinV-7AAD ${ }^{+}$and AnnexinV $^{+} 7 \mathrm{AAD}^{+}$hepatocytes from rats after prolonged consumption of xenobiotics is shown in Fig. 4.

We believe that the observed changes in hepatocyte cell death modes may be induced by cell membrane destruction via peroxidation of polyunsaturated fatty acids and degradation of membrane phospholipid. In particular, we demonstrated that the 
A



Quadrant Statistics

Total Events: 50000

X Parameter: 7-AAD (Log)

$Y$ Parameter: Annexin V(Log)

Quad \% Gated

UL $\quad 0.41$

UR $\quad 1.15$

LL $\quad 98.35$

LR $\quad 0.10$
B

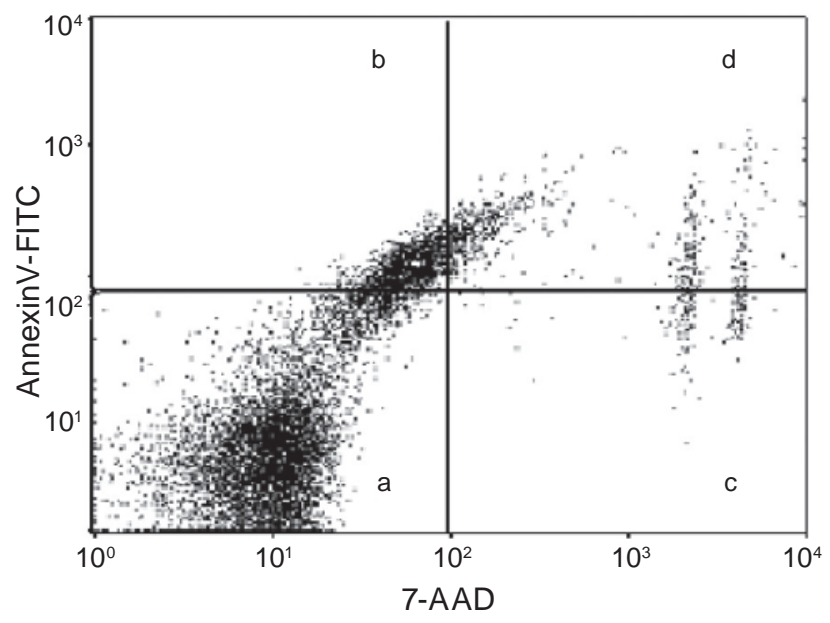

Quadrant Statistics

Total Events: 50000

$X$ Parameter: 7-AAD (Log)

Y Parameter: Annexin V(Log)

Quad \% Gated

UL $\quad 14.98$

UR $\quad 6.81$

LL $\quad 76.54$

LR $\quad 1.67$

Fig. 2. Cytograms of hepatocytes from rats in control (A) and after prolonged consumption of ethyleneglycol at a dose of $1 / 10 D L_{50}$ (B) at different stages of apoptosis/necrosis. Annexin V-FITC/7-AAD staining. a Lower left quadrant - viable cells (AnnexinV-7AAD-cells); $\boldsymbol{b}$ - Upper left quadrant - cells in the initial stage of apoptosis (Annexin $V^{+} 7 A A D^{-}$-cells); $\boldsymbol{c}$-Lower right quadrant - dead necrotic cells (AnnexinV $V^{-} 7 A D^{+}$-cells); $\boldsymbol{d}$-Upper right quadrant - dead cells that are in the stage of late apoptosis/necrosis (Annexin $V^{+} 7 A A D^{+}$-cells)

intake of xenobiotics is associated with activation of lipid peroxidation, confirmed by elevation of TBAreactive substances and conjugated dienes [11].

In our previus studies, we found that xenobiotics significantly affected the structural and metabolic state of the liver, resulted in dysfunction of the monooxygenase system, activated free radical processes against the background of decreased antioxidant reserves, changes in physical and chemical properties and phospholipid composition of hepatocyte membrane [8].

Lipid peroxidation is one of the consequences of oxidative damage. It is known that TBA-reactive substances are highly reactive functional molecules that can impair various membrane functions by cross-linking proteins and phospholipids leading to diminished survival and cell death [11, 12].

Both liver-resident cells and cells that are recruited in response to injury exert pro-inflamatory signals: cytokines, chemokines, reactive oxygen species that contribute to apoptotic or necrotic death of hepatocytes [13].

Thus, intoxication by xenobiotics may induce a massive loss of hepatocytes via necrosis and apoptosis and hence make different hepatic conditions more severe with irreversible liver damage [13]. Activation of cell-death pathway causes inflammation and contributes to the development of many diseases $[8,23]$.

Conclusion. It was found that in subacute toxicological experiment on rats the investigated xenobiotics ethyleneglycol, polyethyleneglycol-400 and polypropyleneglycol at a dose of $1 / 10 \mathrm{DL}_{50}$ caused a change in the plasma membrane of hepatocytes: phosphatidylserine translocation from the inner layer into the outer layer. Such transmembrane phosphatidylserine asymmetry in hepatocytes indicates a higher rate of apoptosis under the action of xenobiotics PEG-400, PPG and EG. 


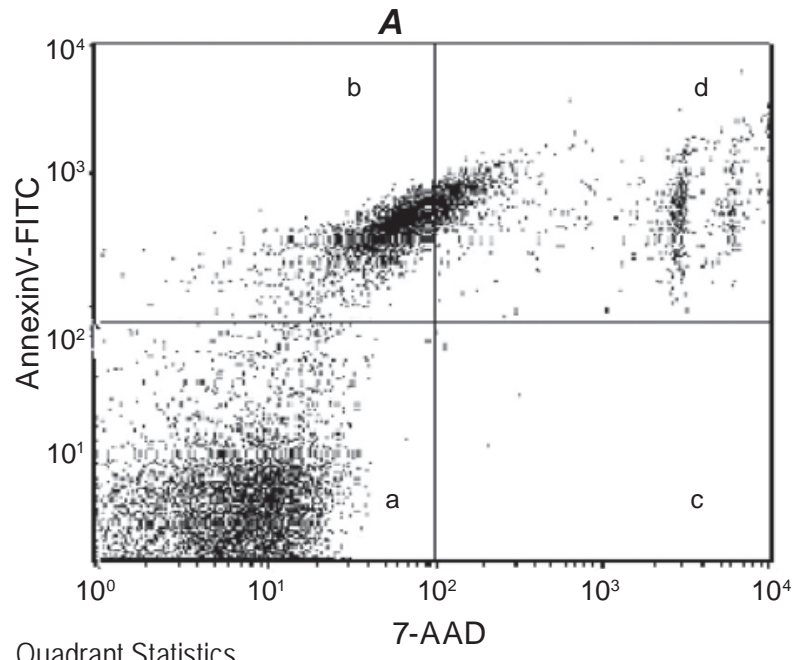

Quadrant Statistics

Total Events: 50000

X Parameter: 7-AAD (Log)

Y Parameter: Annexin V(Log)

Quad \% Gated

UL $\quad 25.50$

UR $\quad 13.76$

LL $\quad 60.70$

LR $\quad 0.04$

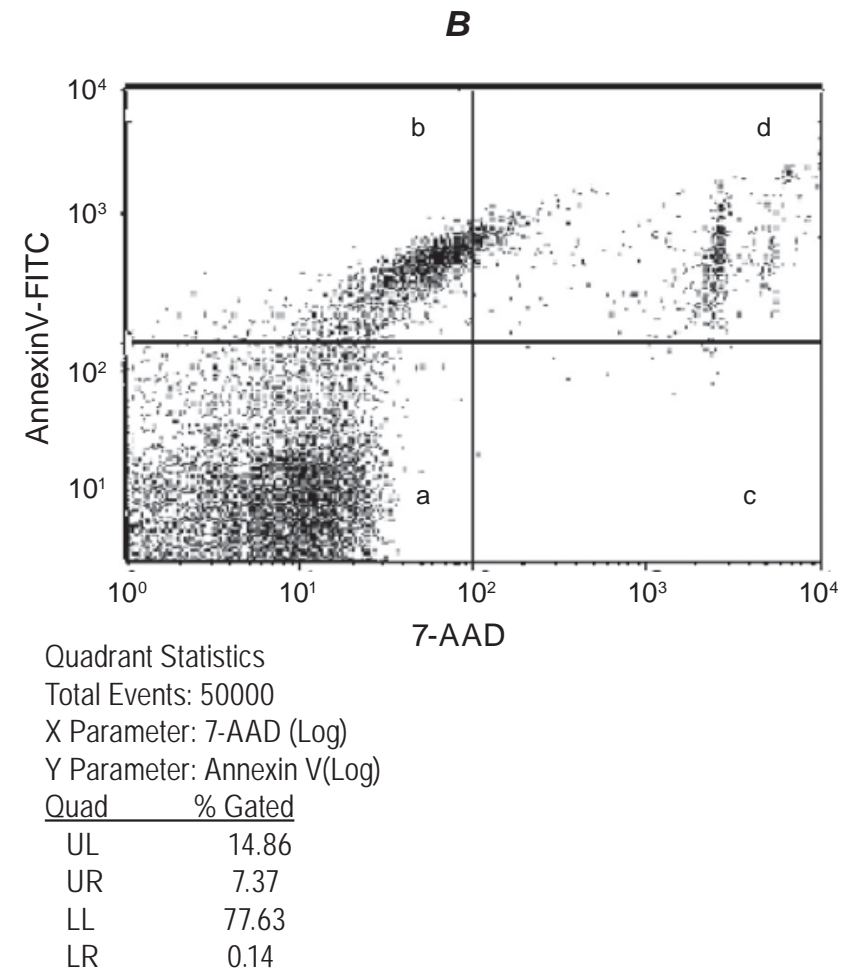

Fig. 3. Cytograms of hepatocytes from rats in and after prolonged consumption of polyethyleneglycol-400 (A) and polypropyleneglycol (B) at a dose of $1 / 10 D L_{50}$ at different stages of apoptosis/necrosis. Annexin $V$ FITC/7-AAD staining

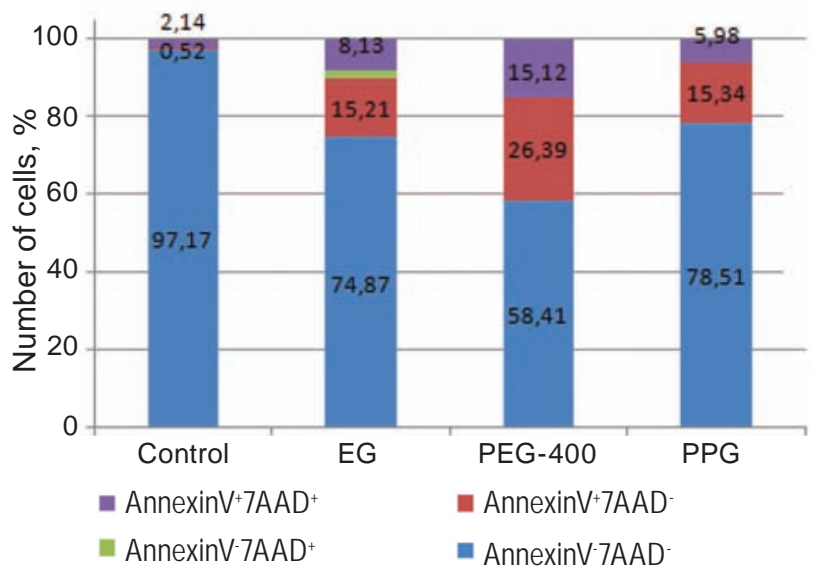

Fig. 4. The percentage of AnnexinV-7AAD-, Annexin $V^{+} 7 A A D^{-}$, AnnexinV $7 A A D^{+}$and AnnexinV $V^{+} 7 A A D^{+}$ hepatocytes from rats after prolonged consumption of xenobiotics: 1-ethyleneglycol (EG), 2-polyethyleneglycol-400 (PEG-400), 3-polypropyleneglycol (PPG) at a dose of $1 / 10 D L_{50}$. Data are presented in the form of $M \pm S E$
ПОРУШЕННЯ ТРАНСМЕМБРАННОӦ АСИМЕТРІЇ ФОСФАТИДИЛСЕРИНУ ГЕПАТОЦИТІВ ЯК МАРКЕР АПОПТОЗУ ЗА ДІЇ КСЕНОБІОТИКІВ НА ЩУРIВ

\section{О. А. Наконечна, Л. О. Бабійчук, A. I. Безродна}

\section{Харківський національний медичний університет, Харків e-mail: bezrodnaya.ai@gmail.com}

Відомо, що несприятливі хімічні фактори довкілля впливають на функціональний стан печінки, активують вільнорадикальні процеси на тлі зниження антиоксидантних резервів, змінюють фізико-хімічні властивості та фосфоліпідний склад мембран гепатоцитів. Метою нашого дослідження була оцінка розподілу фосфатидилсерину у фосфоліпідному бішарі мембран гепатоцитів і стадій апоптозу гепатоцитів у щурів за впливу поверхнево-активних речовин: етиленгліколю (ЕГ), поліетиленгліколю-400 (ПЕГ-400) і поліпропіленгліколю (ППГ) в дозі 1/10 ДЛ Встановлено, що в процесі підгострого токсико- 
логічного експерименту на щурах досліджувані ксенобіотики в зазначеній дозі спричинювали зміну трансбішарового розподілу фосфатидилсерину у фосфоліпідному бішарі мембран гепатоцитів, а саме його появу на поверхні клітини, що $є$ специфічним сигналом для макрофагів та сприяє розпізнаванню і видаленню апоптотичних клітин. Аналіз клітинної смерті гепатоцитів щурів за дії досліджуваних ксенобіотиків в дозі 1/10 ДЛ ${ }_{50}$ виявив збільшення кількості апоптотичних/некротичних гепатоцитів.

К л ю ч о в і с л о в а: ксенобіотики, мембрана, фосфоліпідний бішар гепатоцитів, фосфатидилсерин, апоптоз.

\section{НАРУШЕНИЕ \\ ТРАНСМЕМБРАННОЙ АСИММЕТРИИ \\ ФОСФАТИДИЛСЕРИНА \\ ГЕПАТОЦИТОВ КАК МАРКЕР АПОПТОЗА ПРИ ДЕЙСТВИИ КСЕНОБИОТИКОВ НА КРЫС}

\section{О. А. Наконечная, Л. А. Бабийчук, \\ А. И. Безродная}
Харьковский национальный медицинский университет, Харьков
e-mail: bezrodnaya.ai@gmail.com

Известно, что неблагоприятные химические факторы окружающей среды влияют на функциональное состояние печени, активируют свободнорадикальные процессы на фоне понижения антиоксидантных резервов, изменяют физико-химические свойства и фосфолипидный состав мембран гепатоцитов. Целью нашего исследования была оценка распределения фосфатидилсерина в фосфолипидном бислое мембран гепатоцитов и стадий апоптоза гепапатоцитов у крыс при влиянии поверхностно-активных веществ: этиленгликоля (ЭГ), полиэтиленгликоля-400 (ПЭГ-400) и полипропиленгликоля (ППГ) в дозе 1/10 ДЛ 50 . Установлено, что в процессе подострого токсикологического эксперимента на крысах исследуемые ксенобиотики в указанной дозе вызывали изменение трансбислойного распределения фосфатидилсерина в фосфолипидном бислое мембран гепатоцитов, а именно его появление на поверхности клетки. Это является специфическим сигналом для макрофагов, что способствует распознаванию и удалению апоптотических клеток. Анализ клеточной смерти гепатоцитов крыс под действием исследуемых ксенобиотиков в дозе 1/10 ДЛ выявил увеличение количества апоптотических/ некротических гепатоцитов.

К л ю че в ы е с л о в а: ксенобиотики, мембрана, фосфолипидный бислой гепатоцитов, фосфатидилсерин, апоптоз.

\section{References}

1. Francesco V. Xenobiotics and human health: A new view of their pharma-nutritional role. Pharma Nutrition. 2015; 3(2): 60-64.

2. Julinová M, Vaňharová L, Jurča M. Water-soluble polymeric xenobiotics - Polyvinyl alcohol and polyvinylpyrrolidon - And potential solutions to environmental issues: A brief review. $J$ Environ Manage. 2018; 228: 213-222.

3. Grebnyak NP, Shchudro SA. Relationship of cause and effect between ecological factors and health of teenagers. Ukraine. Health of the Nation. 2008; (3-4): 69-72.

4. Schramm LL, Stasiuk EN, Marangoni DG. Surfactants and their applications. Annu Rep Prog Chem Sect C Phys Chem. 2003; 99: 3-48.

5. National report on the state of the environment in Ukraine in 2013. Kyiv, 2013. 160 p. (In Ukrainian).

6. Zubkova IA, Kryvonos KA, Shcherban MG, Sokol KM. Hygienic assessment of the sanitaryprotective zones of industrial enterprises of Kharkiv. Materials of the XXI International scientific-practical conference "Innovative ways to solve urgent paths of basic industries, ecology, energy and resource saving". AR of Crimea, 2013. P. 284-286. (In Ukrainian).

7. Oxidative stress and biomaterials. Eds. T. Dziubla, D. A. Butterfield. Academic Press, 2016. 389 p.

8. Nakonechna OA. Influence of simple polyesters on phospholipid composition of rat erythrocytes and hepatocytes. Exp Clin Med. 2009; 1: 82-84.

9. Ramana KV, Srivastava S, Singhal SS. Lipid peroxidation products in human health and disease. Oxid Med Cell Longev. 2013; 2013: 583438.

10. Nakonechna OA, Stetsenko S O, Marakushyn DI, Wishnytska IA. Influence of polyethers on phospholipid composition and activity of enzyme membrane-bound complexes in rats brain. Exp Clin Med. 2013; (1(58)): 33-36. (In Ukrainian). 
11. Tebay LE, Robertson H, Durant ST, Vitale SR, Penning TM, Dinkova-Kostova AT, Hayes JD. Mechanisms of activation of the transcription factor Nrf2 by redox stressors, nutrient cues, and energy status and the pathways through which it attenuates degenerative disease. Free Radic Biol Med. 2015; 88(Pt B):108-146.

12. Farag MR, Alagawany M. Erythrocytes as a biological model for screening of xenobiotics toxicity. Chem Biol Interact. 2018; 279: 73-83.

13. Brenner C, Galluzzi L, Kepp O, Kroemer G. Decoding cell death signals in liver inflammation. J Hepatol. 2013; 59(3): 583-594.

14. Gabbianelli R. Modulation of the epigenome by nutrition and xenobiotics during early life and across the life span: The Key Role of Lifestyle. Lifestyle Genom. 2018; 11(1): 9-12.

15. Skinner MK. Endocrine disruptors in 2015: Epigenetic transgenerational inheritance. Nat Rev Endocrinol. 2016; 12(2): 68-70.

16. Dyiment ON. Glycols and other derivatives of oxides of ethylene and propylene. Moscow: Chemistry, 1976. 373 p. (In Russian).

17. Pat., a $1 \mathrm{su} 1510356,5 \mathrm{c} 12 \mathrm{~N}$ 5. 00 Method of separation of hepatocytes. Petrenko A.Yu., Sukach A.N., Kravchenko L.P.;Publ. 29.06.1987. (In Russian).

18. Koopman G, Reutelingsperger CP, Kuijten GA, Keehnen RM, Pals ST, van Oers MH. Annexin $\mathrm{V}$ for flow cytometric detection of phosphatidylserine expression on B cells undergoing apoptosis. Blood. 1994; 84(5): 14151420.

19. Mykhailova OO, Babijchuk LA, Ryazantsev VV, Zubov PM. Estimation of viability and membrane lipid asymmetry of nucleated cells from cord and peripheral blood separated by different methods. Bull Probl Biol Med. 2011; (4(90)): 118-122. (In Russian).

20. Pat. 23499 C12N5. 00 Method of separation of sound cells of the umbilical cord blood. Babyichuk L.A., Riazantsev V.V., Zubov P.M., Zubova O.L., Hryshchenko V.Y. Publ. 25. 05. 2007. (In Ukrainian).

21. Babijchuk LA, Mykhailova OO, Zubov PM, Ryazantsev VV. Evaluation of apoptosis stages and posphatidylserine distribution in membrane of cord and peripheral blood nucleated cells at various cryopreservation protocols. Cell Transplant Tissue Eng. 2013; 8(4): 50-54. (In Russian).

22. Abrahamsen JF, Bakken AM, Bruserud Ø, Gjertsen BT. Flow cytometric measurement of apoptosis and necrosis in cryopreserved PBPC concentrates from patients with malignant diseases. Bone Marrow Transplant. 2002; 29(2): 165-171.

23. Lodish H, Berk A, Kaiser CA, Krieger M, Bretscher A, Ploegh H, Amon A, Martin KC. Molecular Cell Biology. Eighth Edition. 2016. 1170 p.

Received 06.07.2018 